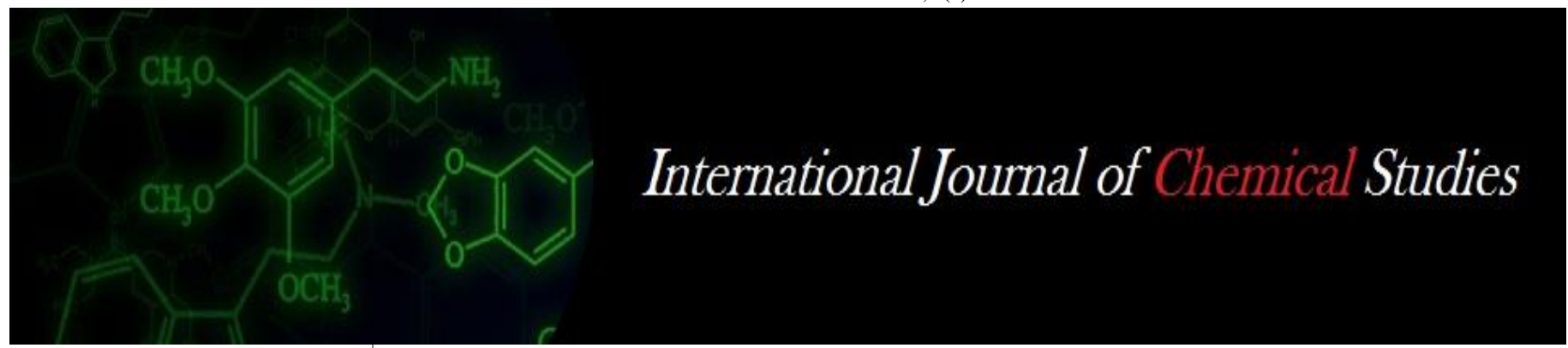

P-ISSN: 2349-8528

E-ISSN: 2321-4902

www.chemijournal.com

IJCS 2020; 8(4): 313-317

(C) 2020 IJCS

Received: 10-05-2020

Accepted: 12-06-2020

\section{DK Jain}

SMS, Plant Protection, KVK,

Badgaon, Udaipur, Rajasthan, India

Hasmukh Kumar

SMS, Agriculturel Engineering,

KVK, Badgaon, Udaipur,

Rajasthan, India

Bahadur Singh

Farm Manager, KVK, Badgaon,

Udaipur, Rajasthan, India

\section{Impact of cluster front line demonstration on mustard in Udaipur district of Southern Rajasthan, India}

\author{
DK Jain, Hasmukh Kumar and Bahadur Singh
}

DOI: https://doi.org/10.22271/chemi.2020.v8.i4e.9707

\begin{abstract}
Sixty seven Cluster Front Line Demonstration (CFLD'S) on Mustard variety NRCHB-101 at farmer's field of two adopted tribal dominated block i.e. Kotra and Falasiya under National Food Security Mission, Govt. of India, were conducted by Vidya Bhawan Krishi Vigyan Kendra, Udaipur during Kharif 2018 in 40 hectare, with active involvement of farmers and scientific staff of KVK. According to Analysis of data the highest grain yield was obtained in demonstrated plots with an average of $16.14 \mathrm{q} / \mathrm{ha}$ as compared to local check with an average of $12.48 \mathrm{q} / / \mathrm{ha}$. The pooled extension gap between demonstrated Practices and farmers practices was recorded $3.66 \mathrm{q} / \mathrm{ha}$. The average net return (39610 $\mathrm{Rs} / \mathrm{ha}$ ) was obtained in the demonstration plots and $28330 \mathrm{Rs} / \mathrm{ha}$ was in local check plots also the average benefit cost ratio was recorded higher in front line demonstrations (1:3.34) as compared to local check (1:2.84) during the evaluation period. The pooled incremental benefit cost ratio (IBCR) was recorded 7.44 with additional return of $11280 \mathrm{Rs} / \mathrm{ha}$.
\end{abstract}

Keywords: Front line demonstration, mustard, technology gap, technology index, extension gap

\section{Introduction}

Mustard, Brassica juncea (Linn.), the important edible oilseed crop, constitutes a major source of edible oil for the human consumption in India and has assumed significance in the national economy by occupying 2nd ranks in acreage next to groundnut and 3rd in world's production of oilseeds. Mustard is the second largest produced oilseed in the world with an area of $37.0 \mathrm{~m}$ $\mathrm{ha}^{-1}$, with the production of $63.09 \mathrm{~m}$ tones and the productivity of $18.50 \mathrm{q} \mathrm{ha}^{-1}$. In India it had the area of $6.3 \mathrm{~m} \mathrm{ha}^{-1}$, with production of $7.37 \mathrm{mt}$ and productivity of $11.90 \mathrm{q} \mathrm{ha}^{-1}$. India contributing 28.3 per cent and 19.8 per cent in the world acreage and production (Anon., 2014) [2]. Rajasthan contributes $45.5 \%$ area and $48.6 \%$ production to the nation. Rajasthan state specially Zone III $b$ is also known as mustard bowl has higher productivity $(15.78 \mathrm{q} / \mathrm{ha})$ as compared to nation (11.9 q/ha). During Rabi 2009-10 mustard was grown in about 7.70 lakh hectare and the average productivity was $15.78 \mathrm{q} /$ ha (AICRP, 2009) ${ }^{[1]}$. Still there is technology and extension gap therefore, it is necessary to assess the technological gap in production and also to know the problems and constraints in adopting modern mustard production technologies Islam et al., (2011) ${ }^{[6]}$. Krishi Vigyan Kendra an innovative science based institution plays an important role in bringing the research scientist face to face with farmers. The main aim of Krishi Vigyan Kendra is to reduce the time lag between generations of technology at the research institution and its transfer to the farmers for increasing productivity and income from the agriculture and allied sectors on sustained basis. KVKs are grass root level organizations meant for application of technology through assessment, refinement and demonstration of proven produce technologies under different micro farming situations in a district (Das, 2007) ${ }^{[4]}$. Keeping in view the low productivity of Mustard, the present study was undertaken to study the impact of Cluster Front Line Demonstration (CFLD) on mustard in 2 different blocks of Udaipur district of Rajasthan. The Cluster Front Line Demonstration (CFLD) is an applied approach to accelerate the dissemination of proven technologies at farmer's fields in a participatory mode with an objective to explore the maximum available resources of crop production and also to bridge the productivity gaps by enhancing the production in national basket.
Corresponding Author:

DK Jain

SMS, Plant Protection, KVK,

Badgaon, Udaipur, Rajasthan, India 
Therefore, the present study has been undertaken to increase the per capita availability of oilseed and popularization of new production technology through Cluster Front Line Demonstrations (CFLD's).

\section{Material and Methods}

For conducting the demonstrations, farmers were identified/ selected following the survey suggested by Choudhary (1999) [3]. The required inputs and technologies were demonstrated time to time visits to the demonstration fields by the KVK's scientist ensured proper guidance to the participatory farmers. The present study was carried out by Vidya Bhawan Krishi Vigyan Kendra, Udaipur with 67 farmers from two tribal dominated adopted block (Falasiaya and Kotra) villages (Turgarh,Dhala and Sulav) under Cluster front line demonstration programme during Kharif 2018.. The soil of FLD's field taken under demonstration was clay loam and the $\mathrm{PH}$ of soil is near about 7.0- 7.5. The improved technology such as improved varieties (NRCHB-101), weed management, seed treatment and plant protection measures were maintained during entire period of research study. Seed treatment done with imidacloprid 48.0\% FS @ $8.0 \mathrm{ml} / \mathrm{kg}$ seed. The seed rate of mustard is kept $4 \mathrm{~kg} /$ ha in demonstration plots. The sowing was done during first week of October to $10^{\text {th }}$ of July2018. The spacing between row to row and plant to plant was $30 \times 10 \mathrm{~cm}$, respectively for the cluster front line demonstration. The fertilizers doses were also given as basal dose as per STR (Soil Testing Report).Weeding and plant protection measures technology were also demonstrated as per recommendations (table-1). The data were collected through personal contact with farmers at farmer's field through crop cutting and after that tabulated and analyzed to find out the findings and conclusion. The statistical tool like percentage used in this study for analyzed data. The extension gap, technology gap and the technology index were work out with the help of formulas given by Samui et al., (2000) ${ }^{[8]}$ as mentioned below:

Extension gap $=$ Demonstration's yield- farmer's yield (control)

Technology gap $=$ Potential yield- demonstration yield

Technology index $=$ Technology gap $/$ Potential Yield x 100

To estimate the impact in terms of monetary benefits, the benefit cost ratio (BCR) analysis of improved technology (IT) over the real farmers' practices (FP) was worked out with the prevailing market value of the crop.

Additional return $=$ Demonstration net return - Farmers practice net return

Incremental $\mathrm{B}: \mathrm{C}$ ratio $=$ Additional return/ Additional cost

\section{Results and Discussion}

The findings of the present research study as well as relevant discussion have been conferred under following points:

\section{Yield Gap}

Yield of the front line demonstration trials and potential yield of the crop was compared to estimate the yield gaps which were further categorized into technology and extension gaps (Hiremath and Nagaraju, 2009) ${ }^{[5]}$. The data presented in table-2 clearly indicated that the yield of mustard seed under demonstration of CFLD's plots was higher as compared to local check which was due to gap analysis and following improved recommended package of practices like use of improved high yielding variety, seed treatment, weed management, plant protection measures etc (table-1). The results shows (table 2) that the pooled seed yield was 16.14 $\mathrm{q} /$ ha which was higher as compared to local plots (12.48 $\mathrm{q} / \mathrm{ha}$ ). The average increased \% yield was 29.35 in CFLD's demonstration plot over local check. However, the obtained seed yield in CFLD's was lower as compared to Potential yield of the variety NRCHB-101 due to raining situation at the time of flowering and pod formation stage of the crop also due to the low soil depth. These finding are well supported and similar results were also observed by Patel et al., (2014) ${ }^{[7]}$ and Sagar et al., (2004) ${ }^{[9]}$.

\section{Extension gap}

The pooled extension gap between demonstrated practices and farmers practices was recorded $3.66 \mathrm{q} /$ ha (Table 2). This Extension gap should be assigned to adoption of improved transfer technology in demonstrations practices which outcome in higher grain yield than the traditional farmer practices. Similarly findings were also observed in mustard crop by Patel et al., (2014) ${ }^{[7]}$.

\section{Technology gap and technology index}

Technology gap is the most important factor play an important role in any impact assessment, which is estimated by potential yield and estimated yield. The average technology gap in the mustard demonstration yield over potential yield was maximum $1.16 \mathrm{q} / \mathrm{ha}$. observed during kharif 2018. The observed technology gap may be attributed dissimilarity in soil fertility status, rainfall distribution, disease and pest attacks as well as the change in the locations of demonstration plots every year. Further, the maximum extension gap of $3.66 \mathrm{q} / \mathrm{ha}$ was recorded in mustard (NRCHB101) demonstrations during kharif 2018. The table 2 also revealed that the technology index was 6.7 percent. The technology index shows the feasibility of the variety at the farmer's field. The lower value of technology index more is the feasibility of technology. This indicates that a gap existed between technology evolved and technology adoption at farmer's field. The similar results were also observed by Sharma et al., (2014) ${ }^{[10]}$. Hence, it can be concluded from the table 2 that increased yield was due to adoption of improved varieties and follow up package of practices of crop.

Table 1: Technology demonstrated under CFLD's and farmers' practices on mustard.

\begin{tabular}{|c|c|c|c|}
\hline $\begin{array}{l}\text { S. } \\
\text { No }\end{array}$ & Practice & Demonstrated practice & Farmer's practice \\
\hline 1 & Variety & NRCHB-101 & Pusa Bold,T-59 ,BIO -902 \\
\hline 2 & $\begin{array}{l}\text { Seed Rate and } \\
\text { Spacing }\end{array}$ & $4 \mathrm{~kg} / \mathrm{ha}$. and $30 \mathrm{~cm} \mathrm{RXR} \mathrm{\&} 10 \mathrm{~cm}$ PXP & $\begin{array}{l}\text { Approximately } 8-10 \mathrm{~kg} / \mathrm{ha} \\
\text { (about double) and } 10-20 \mathrm{~cm} \\
\text { RXR \& } 5-7 \mathrm{~cm} \text { PXP or } \\
\text { broadcasting }\end{array}$ \\
\hline 3 & Seed Treatment & Imidacloprid 48.0\% FS @ $8 \mathrm{ml} / \mathrm{kg}$ seed & No seed treatment \\
\hline 4 & $\begin{array}{l}\text { Manures and } \\
\text { Fertilizers, }\end{array}$ & $\begin{array}{c}\text { Mix } 8-10 \text { ton FYM/ha.before } 3-4 \text { weeks of sowing in soil. Recommended } \\
\text { doses of Nitrogen and Phosphorus }(60: 40 \mathrm{~kg} / \mathrm{ha}), 250 \mathrm{Kg} \text { Gypsum at the time of } \\
\text { sowing as basal (Half dose of nitrozen as basal and half at the time of first } \\
\text { irriagation) }\end{array}$ & $\begin{array}{l}\text { Use of NP as DAP mixing } \\
\text { with seed at the time of } \\
\text { sowing(Inadequate nutrient } \\
\text { supply) }\end{array}$ \\
\hline
\end{tabular}




\begin{tabular}{|c|c|c|c|}
\hline 5 & Weed control & $\begin{array}{l}\text { Pre-emergence- (Immediately after sowing or the next day)-Pendimethalin } 30 \\
\text { \% EC @ } 1 \text { lit/ha } \\
\text { Post-emergence- - Fenoxaprop-p-ethyl @ 750ml/ha at 20 DAS }\end{array}$ & $\begin{array}{l}\text { Inadequate weed management } \\
\text { : One hand weeding but not } \\
\text { proper thining }(\mathrm{p} \times \mathrm{p} 10 \mathrm{~cm})\end{array}$ \\
\hline 6 & $\begin{array}{l}\text { Use of growth } \\
\text { promoter or } \\
\text { micronutrients }\end{array}$ & $\begin{array}{c}\text { Micronutrients (Fe,Mn,Zn,Mo,BO) } \\
@ 1.75 \mathrm{~kg} / \mathrm{ha}(30-35 \mathrm{DAYS}) \text { as foliar spray. }\end{array}$ & No use of micronutrients. \\
\hline 7 & Irrigation & $\begin{array}{c}\text { For irrigated area- if } 2 \text { irrigation } \\
\text { First at 35-45 DAS (before flowering), Second at 70-80 DAS and if one } \\
\text { irrigation that should be at 60 DAS. }\end{array}$ & Not at proper time. \\
\hline 8 & $\begin{array}{l}\text { Plant Protection } \\
\text { Measures }\end{array}$ & $\begin{array}{l}\text { For management of aphids, two foliar spray i.e. first spray at } 40 \text { days and } \\
\text { second after } 15 \text { days of first spray with Imidacloprid } 70 \text { WG @ } 2 \text { gm per } 15 \\
\text { liter of water or Imidachloprid 17.8 SL@ } 250 \mathrm{ml} / \mathrm{ha} \text { at ETL level ( } 25 \text { aphids /10 } \\
\mathrm{cm} \text { apical shoot or central twig) or with dimethoate 30EC @ } 300 \mathrm{~g} \text { a.i./ha.For } \\
\text { management of fungal diseases Myclobutanil or mixture of } \\
\text { Mencozeb+Metalyxil } 1 \mathrm{~kg} / \mathrm{Ha} \text {. }\end{array}$ & $\begin{array}{l}\text { Improper time of spray means } \\
\text { not at ETL and not in } \\
\text { recommended dose. }\end{array}$ \\
\hline
\end{tabular}

Table 2: Productivity, extension gap, technology gap and technology index of mustard as grown under CFLD's and existing package of practices.

\begin{tabular}{|c|c|c|c|c|c|}
\hline \multirow{2}{*}{$\begin{array}{l}\text { Block (village) and number of } \\
\text { beneficiaries }\end{array}$} & Yield q/ha & \multirow{2}{*}{$\begin{array}{c}\text { Increase yield \% over } \\
\text { control }\end{array}$} & \multirow{2}{*}{$\begin{array}{l}\text { Extension } \\
\operatorname{gap}(\mathbf{q} / \mathbf{h a})\end{array}$} & \multirow{2}{*}{$\begin{array}{l}\text { Technology } \\
\text { gap(q/ha) }\end{array}$} & \multirow{2}{*}{$\begin{array}{c}\text { Technology Index } \\
(\%)\end{array}$} \\
\hline & \begin{tabular}{|l|l|}
$\mathbf{I T}^{*}$ & $\mathbf{F P}^{*}$ \\
\end{tabular} & & & & \\
\hline Falasiya (Turgarh and Dhala) - 43 & 16.9313 .15 & 28.74 & 3.78 & 0.37 & 2.13 \\
\hline Kotra(Sulav)-24 & 15.3511 .81 & 29.97 & 3.54 & 1.95 & 11.27 \\
\hline Pooled & $|16.14| 12.48$ & 29.35 & 3.66 & 1.16 & 6.7 \\
\hline
\end{tabular}

*IT- Improved technology; FP- Farmer's Practice

Table 3: Economics of Demonstration and Local Check of mustard as grown under CFLD's

\begin{tabular}{|c|c|c|c|c|c|c|c|c|c|c|}
\hline \multirow{2}{*}{$\begin{array}{c}\text { Block } \\
\text { (village) }\end{array}$} & \multicolumn{2}{|c|}{ Gross cost of cultivation (Rs/ha) } & \multicolumn{2}{|c|}{ Gross Return (Rs/ha) } & \multicolumn{2}{|c|}{ Net Return (Rs/ha) } & \multicolumn{2}{|c|}{ BC Ratio } & \multirow{2}{*}{$\begin{array}{c}\text { Additional Return } \\
(\mathrm{Rs} / \mathrm{ha})\end{array}$} & \multirow{2}{*}{ IBCR } \\
\hline & IT* & FP* & IT* & FP* & IT* & FP* & IT* & FP* & & \\
\hline $\begin{array}{c}\text { Falasiya } \\
\text { (Turgarh } \\
\& \\
\text { Dhala) }\end{array}$ & 16950 & 15500 & 59255 & 45025 & 42305 & 29525 & $1: 3.49$ & $1: 2.90$ & 12780 & 8.81 \\
\hline $\begin{array}{c}\text { Kotra } \\
\text { (Sulav) }\end{array}$ & 16810 & 15200 & 53725 & 42335 & 36915 & 27135 & $1: 3.19$ & $1: 2.78$ & 9780 & 6.07 \\
\hline Pooled & 16880 & 15350 & 56490 & 43680 & 39610 & 28330 & $1: 3.34$ & $1: 2.84$ & 11280 & 7.44 \\
\hline
\end{tabular}

*IT- Improved technology; FP- Farmer's Practice; IBCR- Incremental benefit cost ratio

\section{Economic return}

Table 3 revealed that the average cost of cultivation increased in demonstration practice (16880 Rs/ha) as compared to local check (15350 Rs/ha). Use of improved high yielding seeds, seed treatment, recommended dose of fertilizers, timely weedicide spray, proper pest management strategies etc, all of these are the main reasons for high cost of cultivation in demonstration plots than local check. The figures showed in Table 3 clearly explicated the implication of front line demonstration at farmer's field during the period of study in which average higher net returns (39610 Rs/ha) were obtained under demonstration plots as compared to farmer practices (28330 Rs/ha). Benefit cost ratio was recorded under front line demonstrations $(1: 3.34)$ as compared to farmer practices (1:2.84) during the period of study. The similarly findings was also obtained by Sagar et al., (2018). The above results showed that the integration of improved technology along with active participation of farmer has a positive effect on increase the grain yield and Economic return of mustard crop Production. The suitable technology for enhancing the productivity of mustard crop and need to conduct such demonstrations may lead to the improvement and empowerment of farmers. High benefit cost ratio also advocated the economic viability of the demonstration and motivated the farmers towards adoption of interventions demonstrated. Hence, by conducting front line demonstrations of proven technologies, yield potential of mustard crops can be increased to very great extent. This will subsequently increase the income as well as the livelihood of the poor farming community of tribal areas of India and whole world. 

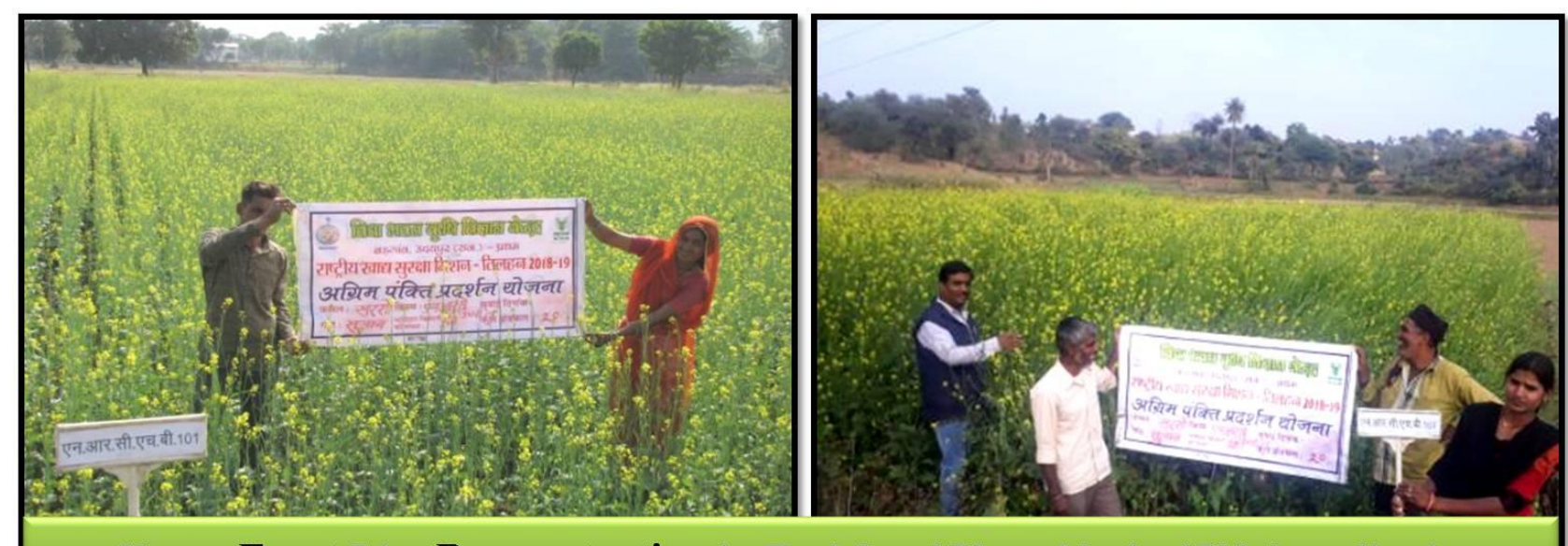

Cluster Front Line Demonstration in Jhadol and Kotra block of Udaipur district.
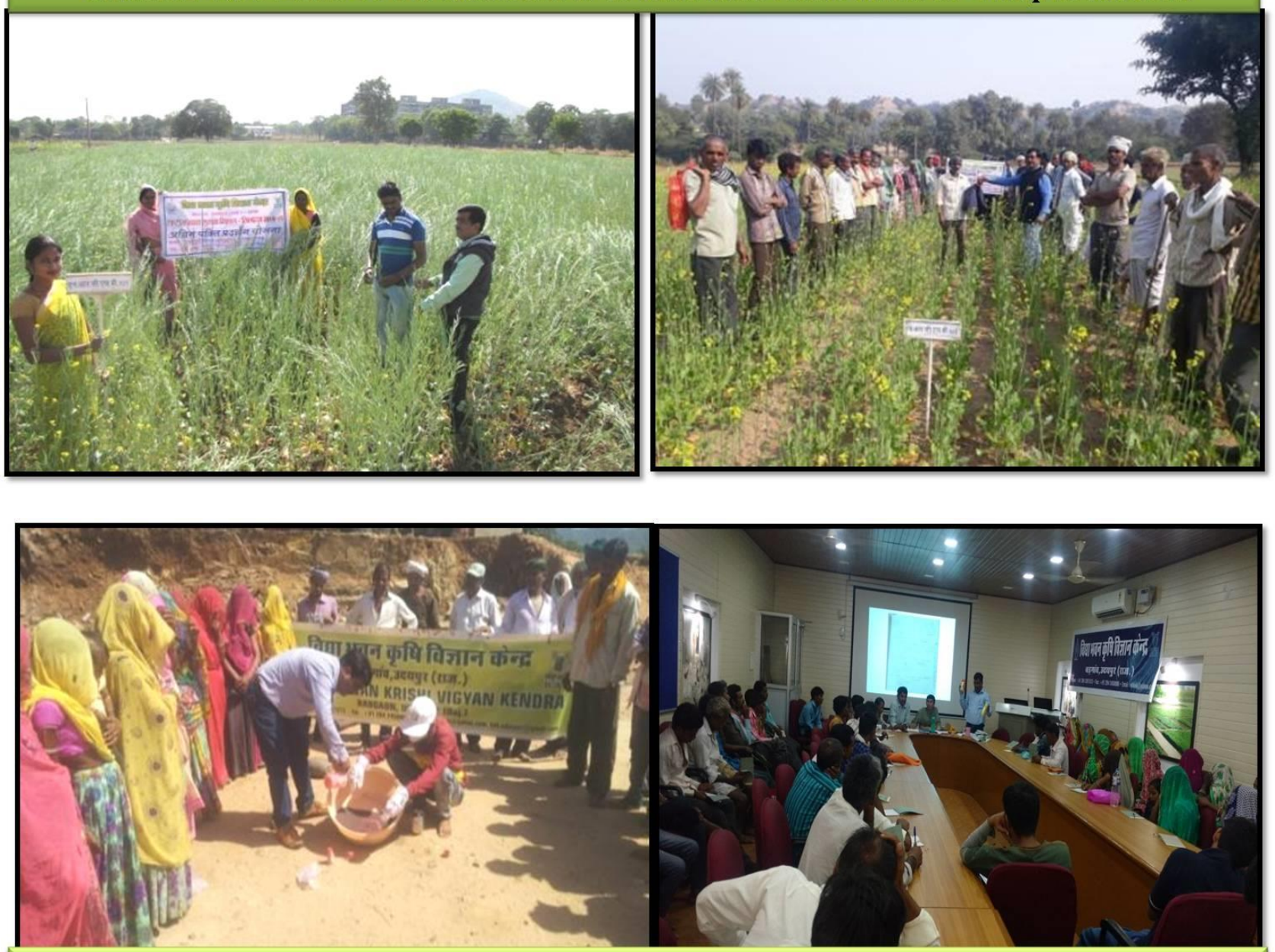

\section{Demonstration of recommended technology under CFLD's}

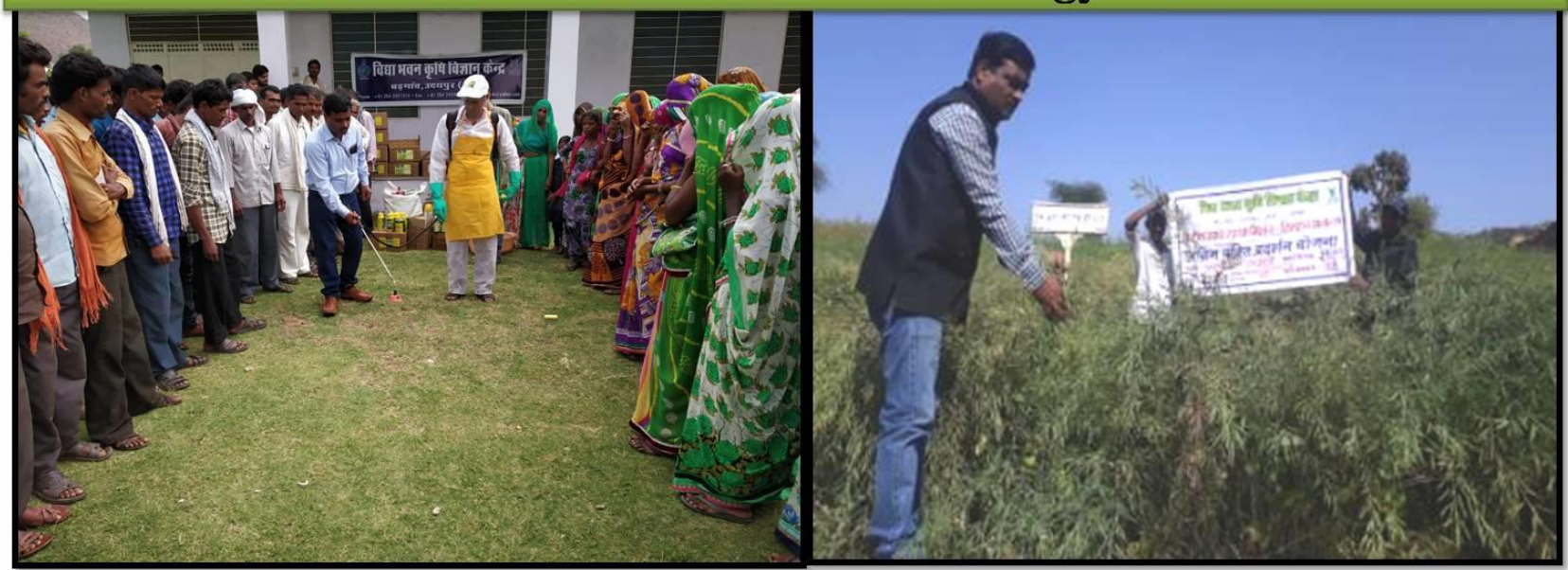




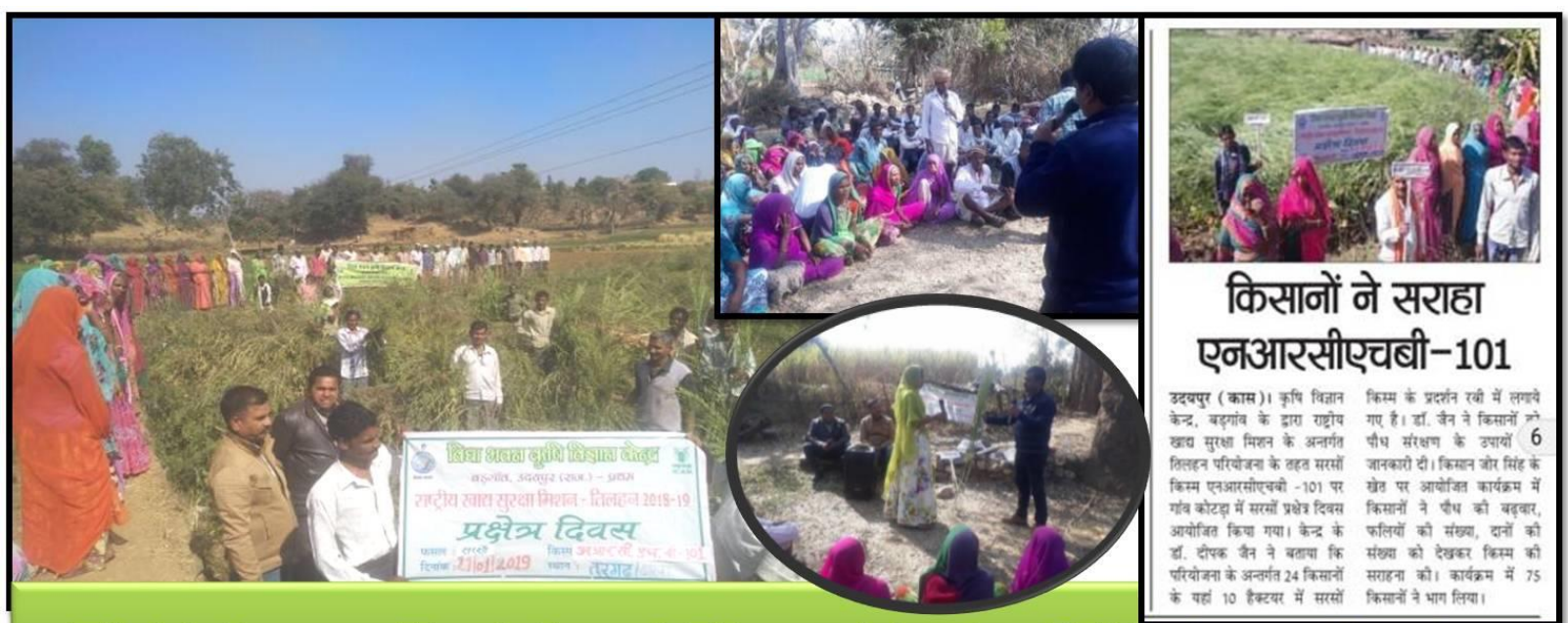

Field day at Jhadol and Kotra block of Udaipur district.

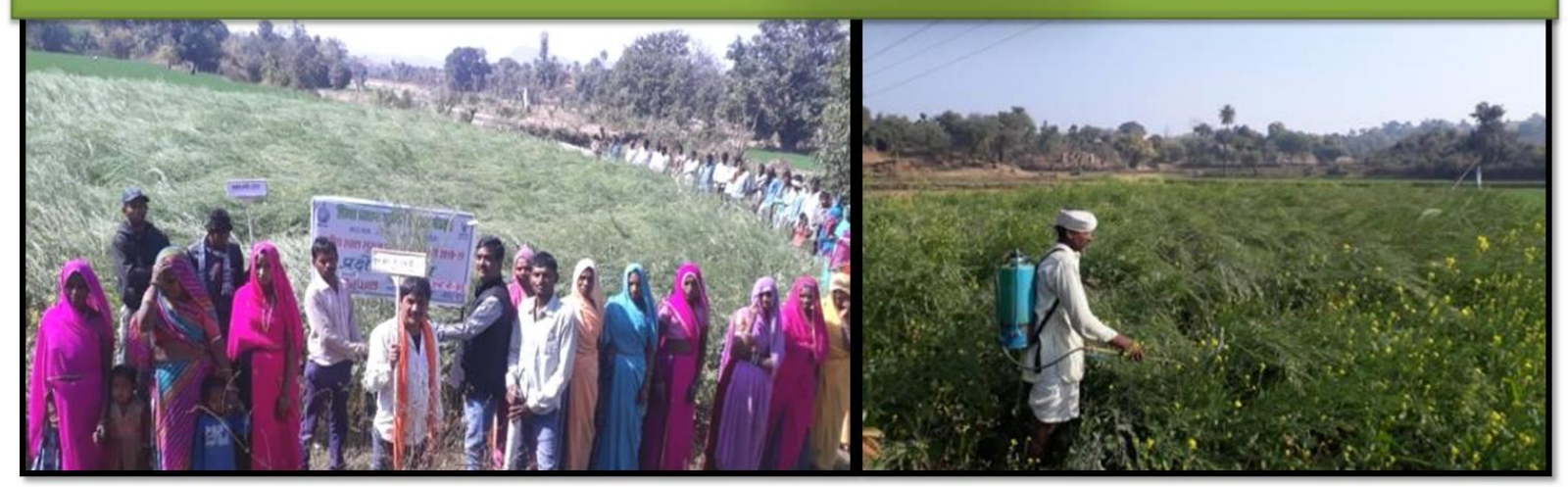

\section{References}

1. AICRP. XVI Annual Report of All India Coordinated Research Project on rapeseed-mustard. Directorate of rapeseed-mustard research, Sewar, Bharatpur (Rajasthan), 2009.

2. Anonymous. Annual Progress Report of All India Coordinated Research Project on Rapeseed and Mustard, National Research Centre on Rapeseed Mustard, Sewar, 3213003, Bharatpur, Rajasthan, 2014, 155.

3. Choudhary BN. Krishi Vigyan Kendra- guide for KVK managers. Publication, Division of Agril. Extn., ICAR, 1999, 73-78.

4. Das Mamoni, Puzari NN, Ray BK Impact of training of skill and knowledge development of rural women, Agricultural Extension Review, 2007; 1(1):29-30.

5. Hiremath SM, Nagaraju MV. Evaluation of front line demonstration trials on onion in Haveri district of Karnataka, Karnataka J Agric Sci. 2009; 22(5):10921093

6. Islam M, Mohanty AK, Kumar S. Correlation growth yield and adoption of urdbean technologies. Indian Research Journal of Extension Education, 2011; 11(2):20-24.

7. Patel RN, Prajapati MM, Dhandhukia RD, Chaudhri FK. Study of front line demonstrations (FLD) on mustard. Adv. Res. Agri. Vet. Sci. 2014; (1, 2):62-64

8. Samui SK, Maitra S, Roy DK, Mondal AK, Saha D. Evaluation of front line demonstration on groundnut (Arachis hypogea L.) in Sundarbans, Journal of Indian Society of Coastal Agriculture Resources, 2000; 18(2):180-183.

9. Sagar RL, Chandra, Ganesh. Evaluation of Frontline Demonstration on Mustard in Sunderbans, West Bengal.
Indian Journal of Extension Education. 2004; 40(3, 4):9697.

10. Sharma H, Sarma R, Sarmah AK, Upamanya GK. Yield Gap Analysis of Toria (Brassica campestris) in Barpeta District of Assam. Indian Research Journal of Extension Education. 2014; 14(2):127-129. 